\title{
A Novel Approach to Spent Fuel Pool Decommissioning
}

\author{
R. L. Demmer \\ Idaho National Laboratory, Idaho Falls, Idaho \\ USA
}

\section{Introduction}

A novel underwater strategy was developed at the INL as an interim action to reduce the hazards associated with maintaining excess SFPs containing water, sludge and other debris. It is estimated that hundreds of these facilities exist around the world. They present a hazard to the environment in that they often leak and may spread contamination. In some cases the pools were maintained to prevent airborne contamination risks if the sides become dry, or to shield a "bathtub ring" (or other debris on the bottom of the pool) of highly radioactive material just below the water's surface. The INL strategy was to vacuum the pool, scrub the sides, filter the water and coat the entire pool to reduce the risks associated with these hazards. Extending this strategy to the more challenging decommissioning of the INTEC-603 pool, with extensive underwater scanning and grouting was a natural progression of the hazard reduction actions.

The underwater coating and cleaning strategy was subsequently found to be of interest in the commercial NPP arena for a deactivation project at the Dresden Nuclear Power Station Unit 1. This project became a cooperative effort between Exelon and Idaho National Laboratory (INL), with shared project planning, equipment, and documentation. The approach was to apply the underwater coating process pioneered at INL. It was successfully modified and deployed by the Dresden Unit 1 SFP team.

The Dresden Station Unit 1 is one of the first commercial nuclear reactors commissioned in the United States. Unit 1 was placed into commercial operation on August 1, 1960, and became the first commercial nuclear power plant built by private industry. It is situated approximately 50 miles southwest of Chicago near the confluence of the Des Plaines and Kankakee Rivers. It shares this site with two other NPPs, Dresden Units 2 and 3.

Unit 1 is a General Electric-designed Boiling Water Reactor. It was originally engineered for a power output of $630 \mathrm{MWt}$, and this was later increased to $700 \mathrm{MWt}$, which generated 210 MW of electricity. Unit 1 had a history of minor steam leaks and erosion in steam piping. It operated until 1978, when it was shut down for retrofitting. Following the Three Mile Island incident in 1979, additional regulations were issued, and a decision was made not to restart Unit 1. The plant was subsequently licensed to possess radioactive material but not to operate and its designation was changed to a SAFSTOR configuration, a Nuclear Regulatory Commission (NRC) interim decommissioning designation. Chemical decontamination of the primary system was completed in 1984. According to an NRC report, the remainder of the 
decommissioning work has been delayed until the other operating units reach the end of their lifetime (US NRC, 2005).

In 2004, a decision was made by Exelon management to reduce the risk of fuel pool leakage by cleaning, draining, and coating the SFP. The Unit 1 tritium groundwater monitoring program indicated that there may have been leakage from the Unit 1 pools. Since that initial indication there has been no further signs of any significant leakage, and the tritium monitoring will continue to be used to provide indication of any possible leakage until all the water is drained from the pools. Recent incidents of SFP leakage, particularly at the Indian Point and Connecticut Yankee NPPs, underscore the necessity of this concern. In the spring of 2004, a conceptual plan was developed to remove the water, process it in the water treatment facility for Units 2 and 3, seal the basin, and thus reduce the SFP leakage risk and maintenance requirements.

Exelon contacted INL because of their newly developed method of successful SFP decommissioning. INL is a Department of Energy (DOE)-owned, contractor-operated nuclear energy development laboratory located 45 miles west of Idaho Falls, Idaho. During 50 years of nuclear research, INL built several SFPs, four of which were scheduled for decommissioning by 2004. These included the Test Area North (TAN) 607 Pool, the Materials Test Reactor (MTR) 603 Canal, the Power Burst Facility (PBF) 620 Canal, and the Idaho Nuclear Technology Engineering Center (INTEC) 603 Overflow Pit. Decommissioning the large TAN-607 SFP was completed ahead of schedule and for less cost than using traditional practices. The size and condition of the INL pools are shown in Table 1 (Whitmill, 2003).

\begin{tabular}{|c|c|c|c|}
\hline $\begin{array}{c}\text { Pool } \\
\text { Designation }\end{array}$ & Volume & Dimensions & $\begin{array}{c}\text { Average Water } \\
\text { Contamination }\end{array}$ \\
\hline TAN 607 & $2,948,4001$ & $14.6 \times 21.3 \times 7.3 \mathrm{~m}$ deep & $1 \mathrm{E}-3 \mathrm{uCi} / \mathrm{L}$ \\
\hline MTR 603 & 446,0401 & $33.5 \times 2.4 \times 5.5 \mathrm{~m}$ deep & $4 \mathrm{E}-2 \mathrm{uCi} / \mathrm{L}$ \\
\hline PBF 620 & 94,5001 & $2.4 \times 4.9 \times 6.1 \mathrm{~m}$ deep & $1 \mathrm{E}-3 \mathrm{uCi} / \mathrm{L}$ \\
\hline $\begin{array}{c}\text { INTEC 603 } \\
\text { (Overflow Pit) }\end{array}$ & 43,4701 & $1.8 \times 2.4 \times 5.2 \mathrm{~m}$ deep & $4 \mathrm{E}-2 \mathrm{uCi} / \mathrm{L}$ \\
\hline
\end{tabular}

Table 1. INL Spent Fuel Pools Completing Underwater Clean and Coat Processes.

\section{The INL approach}

Cleaning and coating an SFP using the underwater coating process requires extensive environmental, safety, and health (ES\&H) documentation and engineering efforts. The set of procedures, permits, and safety analyses for the TAN-607 SFP fills four large binders. Members of INL management reviewed these preparations and procedures during an assessment prior to commencing the fieldwork. An underwater team with nuclear reactor experience, Underwater Engineering Services (UES), was contracted to perform the cleaning and coating work, as shown in Figure 1. Emergency procedures were well-documented and reviewed in a pre-job briefing each workday, and work was coordinated through the facility management. During each shift of underwater diving, an INL senior management representative supervised the contractor's conformance with the safety procedures.

One major component of INL's preparation was to develop an "As-Low-As-ReasonablyAchievable" (ALARA) package. Due to the highly-radioactive nature of certain portions of the TAN-607 pool, the work processes and procedures were scrutinized to meet the tightest 
level of radiological control. Essentially no portion of the work was left to chance in terms of potential skin contamination or overt radiation exposure. This was integrated with the training and experience of the underwater diver's program.

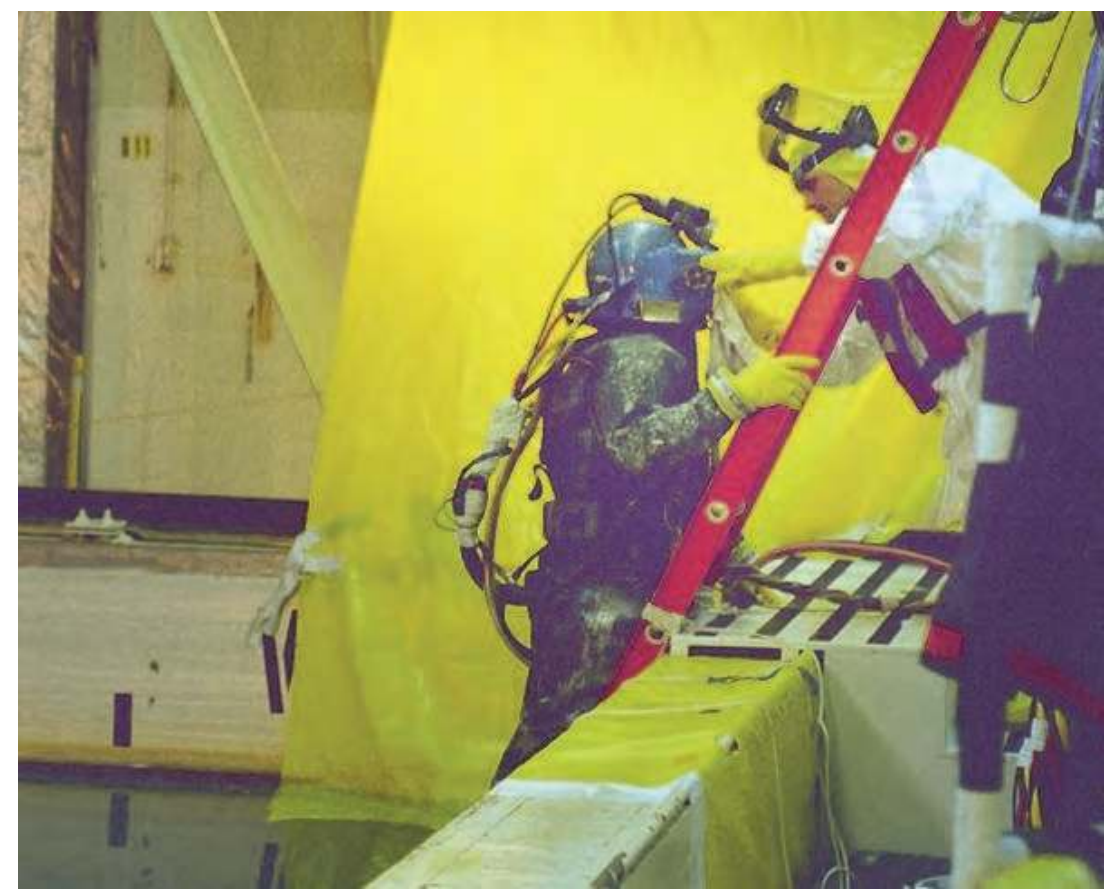

Fig. 1. Diver at INL completing entry into basin for underwater cleaning and coating.

The INL tested 14 different epoxy-based coatings to determine their conformance to SFP requirements (Tripp, 2004). The following criteria were used to evaluate the coatings:

- $\quad$ Ease of application

- Strong adhesion to carbon steel, brick, concrete block, and stainless steel

- No negative effect on water quality

- No hazardous residues left behind

- Proven in other underwater applications

- High cross-link density and pigment to withstand radiation and contamination penetration.

The ease of application was addressed in terms of moderate, but not excessive, viscosity, application thickness, and pot life (pot life is the amount of time a catalyzed coating may be used prior to solidifying). These types of coatings are used in naval applications for recoating ship hulls underwater. UES had previously made applications of one particular underwater epoxy coating in which they had high confidence. A test of that type of coating, UT-15 Underwater Epoxy, manufactured by Picco Coatings Co., determined that it was within the acceptable range of requirements for this work.

Fieldwork commenced in the TAN-607 SFP in the spring of 2003. This pool was the largest at INL to be decommissioned in this series. A larger pool, the INTEC-603 main pool (north 
middle and south basins) has also been deactivated with a modified underwater approach discussed later in this report. The TAN-607 SFP was viewed as a significant but manageable challenge with application to future larger projects. The TAN-607 SFP had been used for storage of a number of different nuclear fuels, the most notable being the damaged Three Mile Island fuel and core debris, which, consequently, led to increased contamination levels in the pool.

The radiological contamination and exposure controls were managed on a real-time basis. While each section of the SFP had been extensively surveyed using remotely-reporting, submersible, extended-reach AMP-100 radiation probes manufactured by Arrow-Tech Inc., each shift of divers also visually surveyed their work area prior to beginning work. Each diver was outfitted with five redundant, remotely-reporting dosimeters multiplexed to the DMC 2000S, manufactured by Merlin Gerin Co. These instruments were integrated into the "dive station" laptop computer that monitored divers' dive times. If two of the dosimeter units failed, or if dose readings exceeded the $500 \mathrm{mR} / \mathrm{hr}$ alarm set point, the diver was required to move to a lower dose area. Industrial guidelines of three-hour dives were maintained; work below $12.2 \mathrm{~m}$ could not exceed 1.5 hours. A team of assistants dressed in anti-contamination clothing and a partially-suited substitute diver were maintained at the entrance to the dive at all times.

The divers averaged 5-8 $\mathrm{mR}$ radiation dose per dive and completed 255 dives prior to the only incidence of skin contamination (out of a total of 411 dives for 1673 dive hours on all four basins). In preparation for the dives, foreign objects and as much of the sludge as possible were removed from the pool. This action, along with the shielding properties of the water and the heavy rubber dive suit, resulted in lower radiation doses. Debris removal was first attempted using long-reach extension poles, buckets on tethers, and/or placing highlyradioactive objects in shielded casks. During a pre-job survey of one section in the TAN-607 basin, a highly-radioactive nut reading $90 \mathrm{R} / \mathrm{hr}$, probably debris from the Three-Mile Island accident, was discovered in the area. Work was stopped until a plan could be formulated to remove the item. It was retrieved using $2 \mathrm{~m}$ long tongs and placed in a stainless-steel bucket. Work continued after this incident with a renewed emphasis on the pre-job surveys. The process of cleaning and coating the TAN-607 SFP began with treating and cleaning the water. UES provided a multi-purpose underwater filter/pump system, manufactured by Prosser, Co., 9-50134-03X. The water was then treated with a calcium hypochlorite to precipitate soluble contaminants. This was not particularly successful because the water turned an opaque brown and required several days of filtration prior to diver reentry. After cleaning the water, a hydraulic hull-scrubber device, like those used to clean boat hulls, was used to clean the pool walls. A large number of paint blisters were found as the wall scrubbing progressed. Every blister required additional scrubbing with a hard-bristle steelwire brush, thus slowing the cleaning and coating process significantly. The next step was to vacuum the floor of the pool. The multi-purpose filtration system was used for this as well.

A special type of paint roller system was used for underwater application of the epoxy coating, which is shown being applied underwater in Figure 2. The system had two separate pumps for the epoxy resin and hardener, which were pumped through separate hoses to a mixing manifold about $1.5 \mathrm{~m}$ from the roller. The roller/extruder system was flexible up to that point, and like a solid wand from there to the roller head.

The first half-hour dive provided several important indications that a successful project was underway. A splash curtain was installed along the area where the diver entered and exited the water, and the wipe down and doffing took place within this area. The diver was rinsed 
off as he exited the pool, and then dried off completely with disposable wipes prior to doffing.

Unexpectedly high dose rates were encountered in two work evolutions. One occurred when a particle became lodged in the ridges of the vacuuming hose that the diver used to clean the bottom. A smooth hose was then substituted so that it would be less likely that particles would become lodged in the hose. On a second occasion, the knee areas of the diver became highly contaminated from kneeling in debris on the pool floor. To facilitate removal of this contamination in subsequent dives, the knees and shoes of the diver were covered with duct tape in such a manner that the tape could be easily removed prior to the divers leaving the basin.

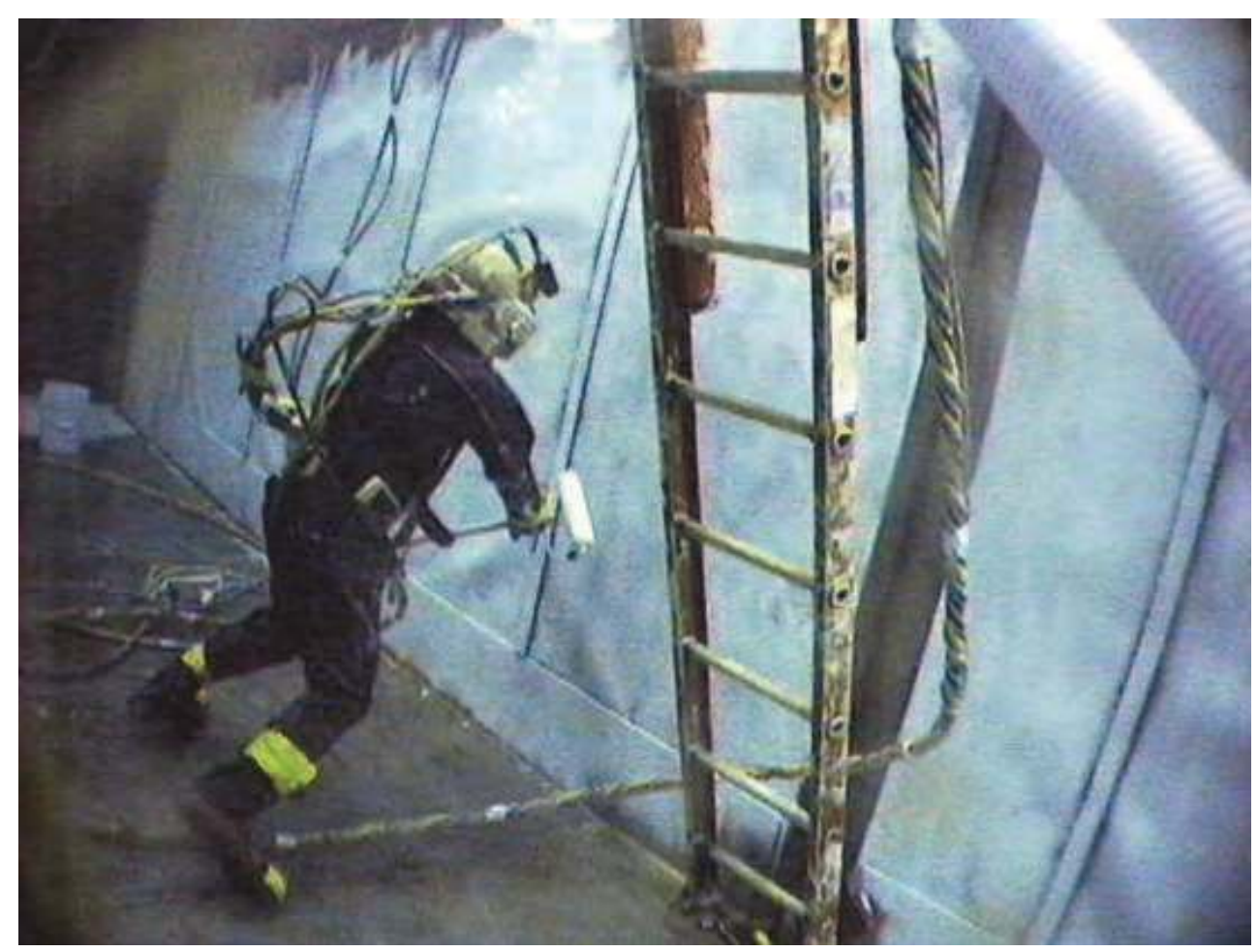

Fig. 2. Special two hose roller system used for wall coating at the MTR pool.

Another unexpected problem was instrumentation malfunction in the wet and highvibration conditions typical during this project. Condensation occurred within some of the radiation detection equipment, particularly the multiplexers. Opening the covers of the dosimeters and letting them dry overnight solved this condensation problem. Some of the wires on the electronic dosimeters were fragile and did not stand up well to the vibration and manipulation of the divers. To address this failure potential, the connection points for the dosimeters were reinforced with electrical tape at the clamp areas, and all the connectors were tightened regularly. 
Overall, the TAN-607 SFP project was highly successful and reduced personnel exposure, project length, and cost from the baseline case. It was projected that the radiation exposure to divers cleaning the pool would be $1056 \mathrm{mR}$; the actual exposure was only $744 \mathrm{mR}$. The highest dose to any diver was $196 \mathrm{mR}$, which was well below that anticipated for even a conventional, non-diver baseline approach. Exposure for the support personnel was projected at $200 \mathrm{mR}$, and was actually only $80 \mathrm{mR}$. Campbell has shown that the integrated basin deactivation project's scheduled duration (6 months for all four basins, about 5200 worker hours) was reduced by 1.5 months (1200 hours) and the cost by $\$ 200,000$ from the $\$ 1.9 \mathrm{M}$ baseline estimate (Campbell, 2004).

\section{In-situ deactivation of spent fuel pools}

Following the INL SFP coating, cleaning and water removal projects, the basins were stabilized with backfill (soil, gravel or grout). This strategy was performed within the hazardous waste laws of Idaho as an interim action protective of health and the environment. The low strength grout used at the INL provides the capability of future removal if that were required. Similar strategies performed at other DOE sites are described as In-situ Deactivation (or decommissioning) or ISD. For those other nuclear facilities this strategy is considered a permanent end state (Langton, 2010, Brown, 1992), like entombment of a facility. While the INTEC-603 43,470 1 Overflow Pit was briefly described in the previous section of this report as a clean and coat action, the larger INTEC-603 (north, middle and south basins, 4,900,000 l) provides an example of the whole basin stabilization process using grout rather than epoxy coating.

There were three phases in deactivating the INTEC-603 SFP. These phases are: 1) Residual cleanout, 2) Validation and 3) Stabilization of remaining contamination. Each of these phases can be very difficult, time consuming and take several years to complete. In the residual cleanout phase, all the spent fuel is removed, equipment is removed and the sludge is removed. The second phase, the validation phase, involves the thorough investigation of the basin to determine that no nuclear fuel remains. This phase also may include extensive sampling and characterization of residual materials for waste disposal. The last phase, stabilization, involves the addition of grout (or another structural material) that prevents intrusion and subsidence. These phases are not rigid and may be revisited over the course of the project.

Residual cleanout can be a very lengthy and difficult stage of the project. Ideally this stage would be part of the operational or (timely) post-operational function of the pool. If consistency with the operation of the pool can be established, it is more likely that trained operators, somewhat knowledgeable about the types of materials that have been used, will be available to identify and remove the items. It is important to stress the continuity of using operators that were trained during the productive life of the pool. They are a ready source of information and skills that will serve the cleanout and deactivation project. This aids the residual cleanout, especially the removal of all spent nuclear fuel or other highly radioactive materials; certainly a priority step in deactivating the pool.

The INTEC-603 pool required an extensive and challenging residual cleanout phase performed well after the post-operational cleanout. At the other INL SFPs the cleanout performed during deactivation was essentially framed within the coating effort. For the INTEC-603 pool the residual cleanout phase was quite extensive and was a project in itself. This pool had a larger accumulation of sludge (some 50,000 kg) and debris that was several 
inches deep. Because the waste was known to contain hazardous constituents (cadmium and lead) a treatability study was performed to determine methods to treat the waste within the Resource Conservation and Recovery Act (RCRA) regulations; the treatment required an engineered grout to encapsulate and stabilize the sludge for disposal. As at other DOE sites, the presence of small bits of residual spent fuel must be taken into account. Thus, a difficult problem of underwater removal and RCRA treatment of highly radioactive sludge becomes even more challenging because of the concern for nuclear criticality.

A system was engineered to remove and treat the sludge in an efficient method that satisfied all the regulatory and safety concerns. A similar sludge cleanout campaign was performed some 20 years prior and a great deal of the technical basis from that previous work was employed during the engineering phase. Essentially the cleanout system was composed of a high-integrity container (HIC) where the sludge was pumped, a integral sacrificial stirring system used to mix the grout in the HIC, and a filtration system in the HIC that separated and returned the water to the basin without the sludge (Croson, 2007). A similar system was used on the Dresden project and is detailed in a following section. Other basin cleanout campaigns had removed and repackaged the spent fuel and removed the fuel storage racks and other in-pool facility equipment at INTEC-603.

The validation phase during the INTEC-603 pool project occurred in parallel with some portions of the cleanout phase. After the racks and equipment were removed, an extensive examination using very sophisticated gamma scanning equipment was employed to map the location and character of the sludge at INTEC-603. In previous INL pools the diver simply surveyed the work area using a remotely reporting instrument prior to starting work each shift. At the Dresden project, the small Remote Underwater Characterization System (RUCS) assisted in the validation role prior to diver entry and cleanup. At the INTEC pool the Multi Detector Basin Scanning Array (Figure 3) was employed as the survey tool. This scanning array is composed of three sections containing gamma detection instruments and is specifically designed to be used with the INTEC-603 crane system and to traverse channels in the pool floor. Since the overall residual cleanout is not complete until the sludge is removed, the validation phase was performed after equipment removal but prior to sludge removal.

In the stabilization phase the grout development, delivery and pool water removal aspects of the INTEC-603 project were revealed. A special grout was formulated with admixtures to have high flowability, cure underwater, be self-leveling and maintain a (low) $1724 \mathrm{kPa}$ strength. After extensive laboratory testing, the grout was prepared on-site in a batch plant and pumped into the basin using $10 \mathrm{~cm}$ hoses. Grout was directed into the center of the basin and allowed to flow to the outside. As the grout was injected into the basin, the displaced water was filtered and pumped to the Idaho CERCLA Disposal Facility (ICDF), a large waste water evaporation pond maintained at the INTEC facility. Grout lifts were generally about $60 \mathrm{~cm}$ thick, with different sections of the pool (north middle and south) receiving lifts on different days allowing curing of the different sections for at least one day.

\section{Deactivating the Dresden Unit 1 SFP}

The decommissioning of Unit 1 actually began more than 25 years prior to the SFP campaign. In 1978, reactor operations were suspended and defueling took place. In 2002, the fuel and fuel pool equipment, such as the racks and accessories, were removed. Some cleaning had been performed in the SFP, but no campaign had been waged to completely gut the pool. When the racks were removed, they were cut off at floor level leaving 
protrusions as high as $10 \mathrm{~cm}$. The water quality had deteriorated significantly, and there was no longer any appreciable visibility below the water line.

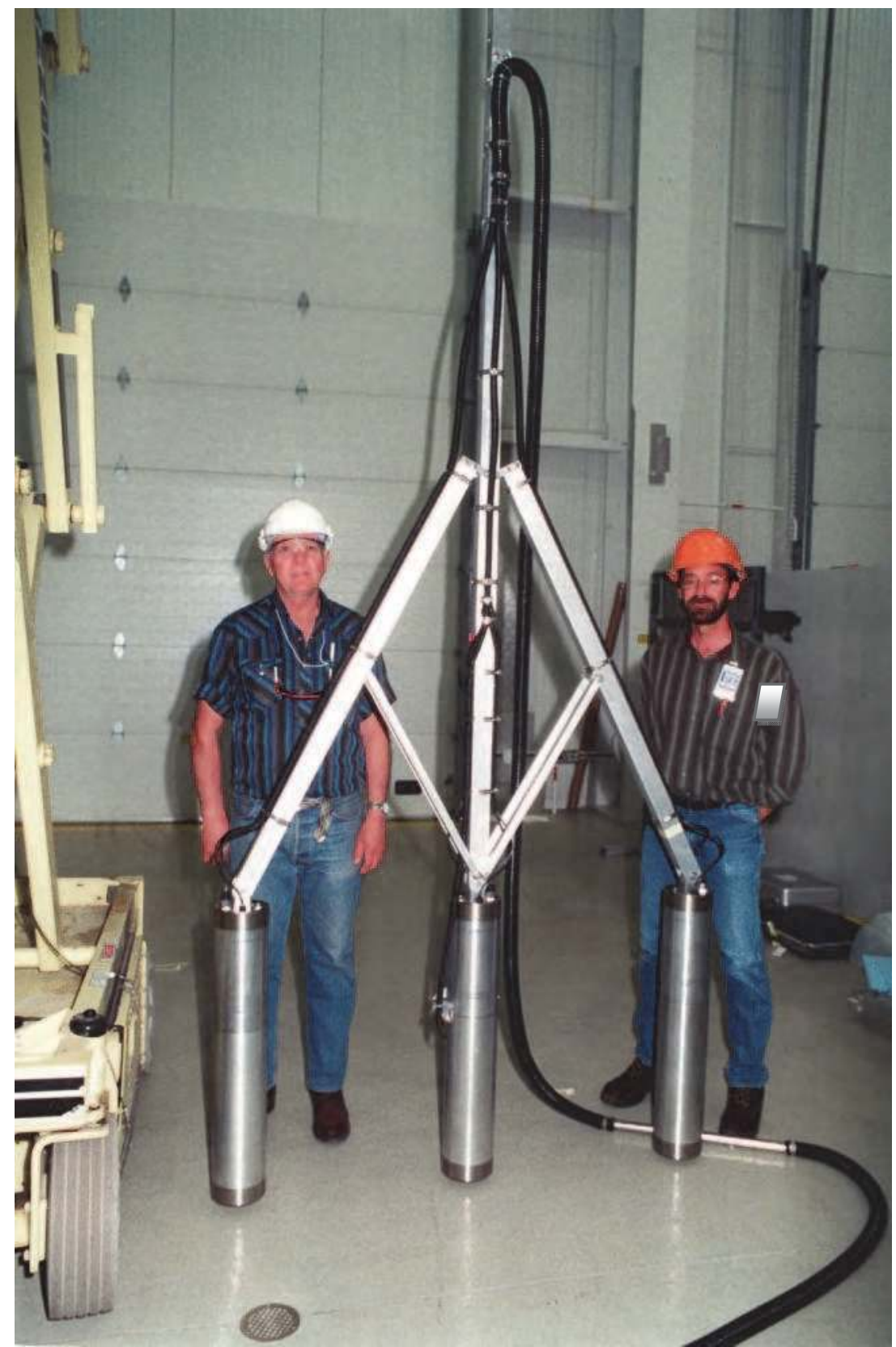

Fig. 3. Multi Detector Basin Scanning Array for INTEC-603. 
The Unit 1 team was planning a cleanup of the SFP using long-handle tools and coating the pool as the water was lowered. This is a conventional method of SFP cleanup, but poses some concerns. The primary concern was the potential for high airborne contamination by allowing contaminated poolsides to be exposed during the draindown. Another concern was the length of time involved in slowly removing water and treating the walls. The disposal of water had to be scheduled with the operating unit's $2 / 3$ treatment system. Theavailability of the $2 / 3$ system could not be assured over wide periods of time, but could be used on an available space and time campaign basis.

The INL underwater coating process was attractive to the Unit 1 team for a number of reasons. First, INL had no airborne contamination problems during the SFP coating projects. Second, with the underwater coating process, there is little concern about scheduling for draining away the pool water; the water can be taken away at any time after the cleaning and coating are completed without impacting the operating unit or the decommissioning schedule. No strain injuries occurred during the INL decommissioning projects while the extensive use of long-handled, underwater tools to clean and paint the pool had a high risk of these injuries. Using divers allows more successful cleaning of the pool bottom and closer cutting of pool equipment. Previously, cutting was accomplished using long-handled cutting tools that left $10 \mathrm{~cm}$ rack stubs. Naturally, the reduced schedule, cost, and radiation dose shown in the TAN-607 SFP project was an advantage.

The Dresden Unit 1 SFP was designed with distinct portions that have different depths, functions, and kinds of equipment. The SFP is " $\mathrm{L}$ " shaped with the main body composed of two separate pools - the storage pool and the transfer area. The storage pool is $6.1 \times 7.6 \times 7.9$ $\mathrm{m}$ deep and the transfer area is $6.1 \times 7.6 \times 13.6 \mathrm{~m}$ deep. The storage pool had contained spent-fuel racks that had been bolted to the floor, but were previously removed. In the transfer area, fuel could be examined and packaged, and maintenance could be performed on reactor components. These two pools were connected with a gateway that could be closed between them. The transfer area was connected to the reactor compartment by a $2.1 \mathrm{x}$ $4.6 \times 18 \mathrm{~m}$ transfer channel.

Preparations for the underwater coating process began after Exelon management had reviewed decommissioning options. The underwater coating process is not intuitively safer industrially and radiologically, but is proven by INL to be safer statistically. An independent dive contractor, Underwater Construction Company (UCC), was contracted as a preferred provider in the Exelon nuclear system and was tasked with underwater coating process. UCC had performed similar types of nuclear jobs involving coatings at reactors.

An underwater survey of the SFP was also a key initial activity. The pool condition and remaining items in the pool were documented from previous cleaning efforts, but a current survey and up-to-date pictures or video were not available. INL provided an operator and the RUCS which is essentially a small, tethered submersible tool to provide video and radiation dose measurements. Although the RUCS system was not a calibrated Exelon unit, its dose measurements were adequate for development of the ALARA plan. The RUCS showed that the floor had general dose readings of 2-3 Rem/hr, with hot spots up to 11 Rem/hr, but that the general pool dose was less than $10 \mathrm{mR} / \mathrm{hr}$. The in-depth survey also identified additional items in the pool not previously visible from above.

The Dresden Unit 1 SFP project proceeded in a series of tasks that took more than a year to complete. Table II shows the tasks and associated schedule required to perform this work. Each task is not discussed in detail, but some of the more interesting activities are examined. 
The overall project took considerably longer than expected, primarily because of the resource drain caused by scheduled work on other Exelon reactors. Work on operating reactors always took precedence over decommissioning work. This was principally manifested in the non-availability of Radiation and Contamination Technicians (RCTs). Thus, decontamination tasks that were expected to take a few months lasted an entire year.

The most extensive activity involved in the underwater coating process was the water cleanup task. The water in the SFP required treatment for two main reasons: first, there was a considerable amount of algae on the surface, and second, the general water condition was moderately contaminated. The bottom was not visible, and the sides of the pool were essentially invisible below the algae layer. Since visual contact with the diver was required at all times, no diver work could start until the water was treated and visibility was adequately restored. There were other reasons to maintain as much cleanliness in the water as possible as well. Beyond the need for visual contact, higher cleanliness contributed to lower radiation doses and contamination on the diver's suit. This made the job of avoiding skin contamination much easier. Cleaning the water also permitted the water to meet the $2 / 3$ system requirements without further remedial treatment.

The process of cleaning the water required a considerable amount of technology. A specialist in the field, Duratek Inc., was contracted to achieve and maintain water quality. The first step was to "shock" the water with the addition of 10 to15 parts-per-million (ppm) hydrogen peroxide. The hydrogen peroxide primarily served to kill the algae and bacteria. After the initial injection of the peroxide, the water turned dark brown and remained this color for several weeks. The peroxide injection system allowed the use of ultraviolet light and ion-exchange after a few days, once the algae were destroyed.

A system known as the UFV-100 "Tri-Nuc" Filter System, manufactured by Tri-Nuclear Corporation, was placed in the pool to maintain long-term water quality. The Tri-Nuc is a canister-type, shielded filter about $0.8 \mathrm{~m}$. long and $18 \mathrm{~cm}$ in diameter. It is an easilymaintained, self-contained system with a submersible pump. After the peroxide injection and three weeks of Tri-Nuc filter operation, the pool water became clear and maintained clarity throughout the project. Over the course of the project, 50 of the Tri-Nuc filters were used. A skimmer system was added to the Tri-Nuc to clear floating algae debris. The underwater diving contractor provided a separate vacuum/filtering system consisting of a pump and eight-38 cm filters on a manifold (see Figure 3). Though this system helped to maintain water clarity, its primary purpose was to contain the paint chips and floor debris. A "rock catcher" screen was used on the UCC system to prevent larger particles from going through the pump.

Following the filtration and water treatment tasks, the wall and floor surfaces were cleaned and prepared. At the start of each work shift, the work area was surveyed using an underwater dosimeter. The floor surface was thoroughly vacuumed using the UCC vacuuming system. The stubs left from previous fuel rack removal were cut with a plasma torch. These were removed along with other small debris so that the floor area was basically clean and free of obstruction. While the walls of the INL SFPs were cleaned using the hull scrubber, the Unit 1 walls were cleaned using hydrolasing. Hydrolasing uses high-pressure water recycled into the pool to blast off grime and loose paint. If the paint came off or blistered paint was present, the areas were cleaned with a $3 \mathrm{M}$ Scotch-Brite ${ }^{\circledR}$ pad prior to recoating.

Several devices were used to afford easier pool access, greater visibility, and reliable diver communication. A portable scaffolding device, much like a window cleaner's or painter's 
work platform, was used in the wall-cleaning and coating. It was easily raised or lowered to different work levels. Underwater lights were used to provide the divers with better visibility, and inexpensive underwater cameras were employed by the engineers to supervise progress. Voice communication devices were installed in the divers' helmets. Additionally, each suit was pressure-tested for leaks and thoroughly surveyed for contamination prior to each dive.

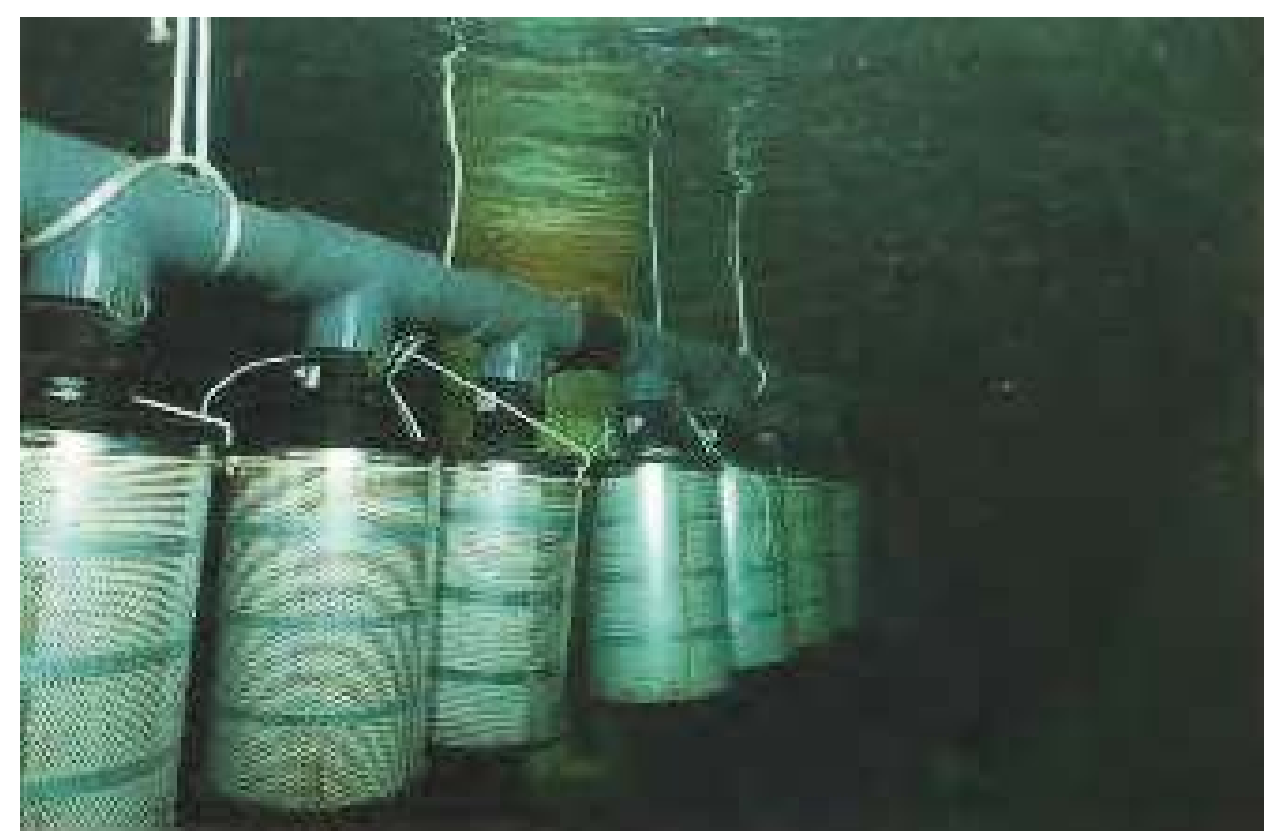

Fig. 4. UCC vacuuming filtration system underwater manifold.

The pool and cleanup equipment required some on-site modification during the course of the project. A large water heater was used to raise the water temperature from about 15 to $21^{\circ} \mathrm{C}$. This enabled more comfortable diving and ensured that the pool walls were at an appropriate temperature for proper coating adhesion. The paint flow through the system was initially slow and somewhat inefficient, so a heated "trace" line was added to the single delivery hose lines and the paint was reformulated to achieve a lower viscosity. The most serious problem was that the mixing lines were too far from the paint roller head. The paint began solidifying before it reached the roller because of the long mixing time while the resin and hardener traveled through the hose, so the mix point was moved to within $1.2 \mathrm{~m}$ of the paint roller head. Heavy, stainless-steel buckets were used to transport floor debris, like nuts, bolts, and pieces of basin equipment. A long-reach pickup device was fabricated from a pair of Vice-Grips. This tool, like the long-handled tongs used at INL, was invaluable for moving radioactive items.

During previous cleanout activities, two large fuel transfer fixtures had not been removed from the lower level of the transfer channel. These fixtures, called "elephant's feet," resembled large, inverted flower pots about $1 \mathrm{~m}$ in diameter and $2.1 \mathrm{~m}$ tall. The project engineers were uncertain whether to cut the elephant feet up and remove them, or to 
decommission them in place and simply paint them. The final decision was to cut and remove them, thereby completely cleaning the SFP and leaving fewer future liabilities.

Normal dive duration was about three hours with two divers in the water at any one time. Two dive shifts were typically performed during a workday. Divers first cleaned and coated the top $3 \mathrm{~m}$ of the entire fuel pool, and then the pool was drained down to that level. This allowed the areas below $12.2 \mathrm{~m}$ to be cleaned with the regular three-hour dive limitation instead of a reduced 1.5 hour limit for dives below $12.2 \mathrm{~m}$. While highly-contaminated items were found in the SFP (1 to $50 \mathrm{Rem} / \mathrm{hr}$ ), the working dose for the divers was 1 to $50 \mathrm{mr} / \mathrm{hr}$ due to the shielding properties of the water.

Several different types of waste were generated during the SFP project. Two types of filter wastes were generated: Class A waste (Tri-Nuc filters) and Class C waste (underwater vacuuming filters). All filters were removed from their respective systems, allowed to drain above the pool, and air-dried. The 50 Tri-Nuc filters were placed in on-site storage. Eighty vacuuming filters were shipped off-site and compacted. Two buckets of miscellaneous parts and equipment were collected from the floor. Special radiological instructions were prepared to facilitate removing those items from the pool. One highly radioactive item was an in-core fission chamber detector reading about $70 \mathrm{Rad} / \mathrm{hr}$. This item contained a small amount of special nuclear material and had to be handled and accounted for separately. A 2001 barrel of general dirt, corrosion products, and paint chips was also collected from the vacuuming screens. All of the solid debris was air-dried, packaged as Class A waste, and held for future disposal.

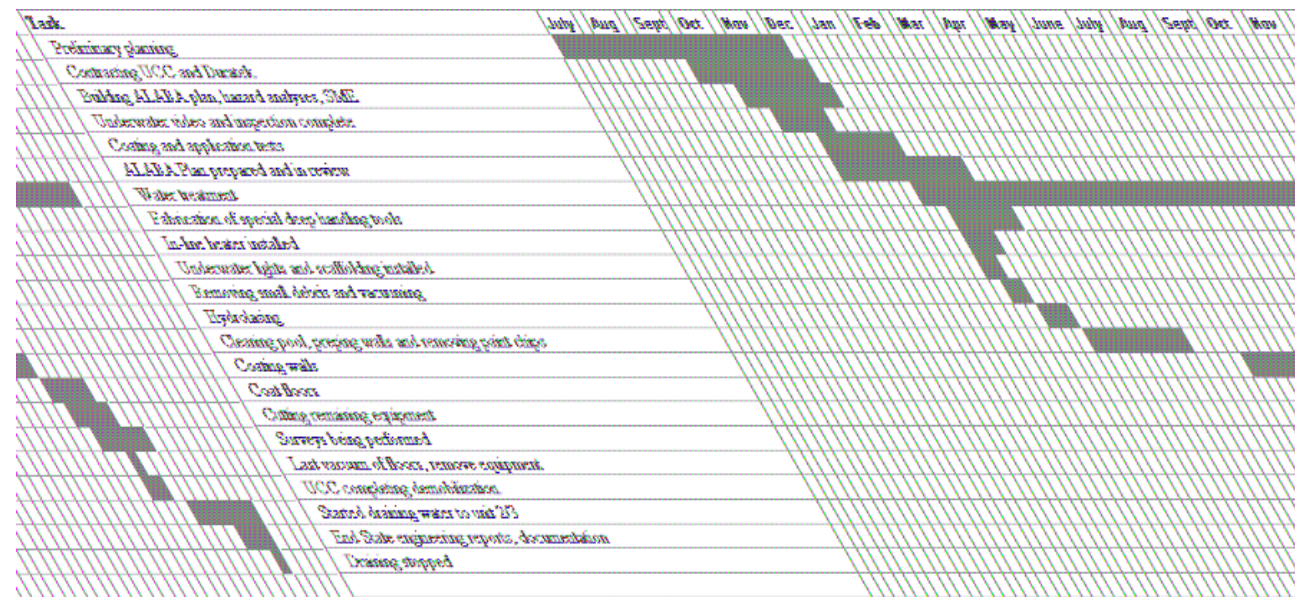

Table 2. Task schedule for the Dresden Unit 1 SFP Underwater Coating Process.

The project was successful, with less overall worker time and exposure. No significant safety incidents were encountered. The project was estimated to require 14,065 hours to complete, with a 22 Rem dose total. The actual number of hours needed was 10,186, with only a 3.59 Rem dose total. There were 281 dives completed with no skin contamination incidents. The water treatment systems were successful at cleaning the SFP water from out-of-specification levels of contaminants, algae, and bacteria to within processing requirements for the Unit's $2 / 3$ systems. 


\section{Lessons learned}

During the SFP deactivation projects (INL and Dresden Unit 1), a number of lessons were learned, the most significant of which are listed below:

- Nuclear trained divers must be used for these projects. There is no substitute for trained and experienced divers. They know the proper contamination control processes for this kind of project and are most effective for difficult operations. These trained individuals will be the key operating personnel when the work goes forward.

- High-quality water treatment systems are required to attain and maintain water clarity and low contamination. This is essential to diver productivity and contamination-free operations.

- In both the TAN and Dresden pools the water turned brown after initial treatment, probably from high mineral and algae content. High concentrations of minerals and algae are common with old spent fuel basins, especially if they have not been under water treatment regimes pending decommissioning. Preparations should be made early to filter the residual mineral/algae that may come from initial water treatment (like chemical "shock" treatments).

- Unusual and unexpected objects (probably highly contaminated) are likely to be found in SFPs. Work areas should be surveyed periodically using the waterproof dosimeters. Some flexibility with special procedures and extended reach tools should be planned into the work. Simple tools like inexpensive underwater cameras and Vice-Grips can be effectively employed.

- Maximizing the use of "off-the shelf" items (such as scaffolding, waterproof lights and cameras and even the marine hull scrubber) reduced the cost of special design and fabrication for some equipment

- Coating areas with loose or blistered paint will significantly slow the project and consume much more of the coating resources. During the INL SFP decommissioning project, the delays were significant, and as much as $50 \%$ more paint was required due to blistered paint.

- The RCTs and support personnel should remain consistent over the project. The most capable personnel should be chosen to monitor, clean, and check equipment, and then should be left in place as a dedicated team.

- Epoxy coatings may have complicated application requirements. Ensure that the manufacturer has optimized viscosity for roller application and that temperature requirements are met. Use a two-hose application system if possible.

- After about two years of service, the coating at Dresden became loose in some wall areas. This may point to a lack of "profile" in preparing the wall using a hydrolaser. This did not happen using the hull scrubber at INL. It is recommended that an abrasive technique, like the hull scrubber, be employed in surface cleaning.

\section{Acknowledgments}

This work was supported through funding provided by the U.S. Department of Energy (DOE) to the Idaho National Laboratory, operated by Battelle Energy Alliance, LLC, under DOE Idaho Operations Office Contract DE-AC07-05ID14517. The submitted manuscript was authored by a contractor of the U.S. Government. Accordingly, the U.S. Government retains a nonexclusive, royalty-free license to publish or reproduce the published form of this contribution, or allow others to do so, for U.S. Government purposes. 
This information was prepared as an account of work sponsored by an agency of the U.S. Government. Neither the U.S. Government nor any agency thereof, nor any of their employees, makes any warranty, express or implied, or assumes any legal liability or responsibility for the accuracy, completeness, or usefulness of any information, apparatus, product, or process disclosed, or represents that its use would not infringe privately owned rights. References herein to any specific commercial product, process, or service by trade name, trademark, manufacturer, or otherwise, does not necessarily constitute or imply its endorsement, recommendation, or favoring by the U.S. Government or any agency thereof. The views and opinions of authors expressed herein do not necessarily state or reflect those of the U.S. Government or any agency thereof.

The author would like to acknowledge the assistance of the following people: Joseph Panozzo and Raymond Christensen of Exelon Corp, Dr. Steven Bakhtiar and Randall Bargelt of the Idaho National Laboratory

\section{References}

Brown, G. A., et al, "In Situ Decommissioning - the Radical Approach for Nuclear Power Stations", Proceedings of the Institution of Mechanical Engineers 1847-1996, 1992.

Campbell, J., "Integrated Basin Closure Subproject Lessons Learned," September 2004.

Croson, D. V., et al, "Idaho Cleanup Project CPP-603A Basin Deactivation", Waste Management Conference (WM07) Proceedings, 2007.

Langton, C. A., et al, "Svannah River site R-Reactor Disassembly Basin In-Situ Decommissioning", Waste Management Conference (WM10) Proceedings, 2010.

Tripp, J. L., et al, "Underwater Coatings Testing for INEEL Fuel Basin Application for Contamination Control," INEEL/EXT-04-01672 Rev. 0, February 2004.

United States Nuclear Regulatory Commission (US NRC), Dresden Unit 1, http://www.nrc.gov/info-finder/decommissioning/power-reactor/dresdennuclear-power-station-unit-1.html, web page last accessed September 2007.

Whitmill, L. J., et al, , “Deactivation of INEEL Fuel Pools," INEEL/INT-03-00936 Rev. 0, August 2003. 


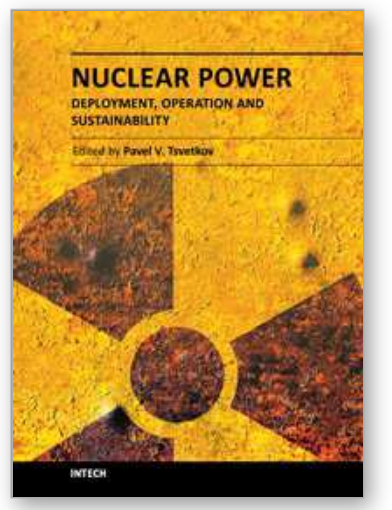

\author{
Nuclear Power - Deployment, Operation and Sustainability \\ Edited by Dr. Pavel Tsvetkov
}

ISBN 978-953-307-474-0

Hard cover, 510 pages

Publisher InTech

Published online 09, September, 2011

Published in print edition September, 2011

We are fortunate to live in incredibly exciting and incredibly challenging time. Energy demands due to economic growth and increasing population must be satisfied in a sustainable manner assuring inherent safety, efficiency and no or minimized environmental impact. These considerations are among the reasons that lead to serious interest in deploying nuclear power as a sustainable energy source. At the same time, catastrophic earthquake and tsunami events in Japan resulted in the nuclear accident that forced us to rethink our approach to nuclear safety, design requirements and facilitated growing interests in advanced nuclear energy systems. This book is one in a series of books on nuclear power published by InTech. It consists of six major sections housing twenty chapters on topics from the key subject areas pertinent to successful development, deployment and operation of nuclear power systems worldwide. The book targets everyone as its potential readership groups - students, researchers and practitioners - who are interested to learn about nuclear power.

\title{
How to reference
}

In order to correctly reference this scholarly work, feel free to copy and paste the following:

R. L. Demmer (2011). A Novel Approach to Spent Fuel Pool Decommissioning, Nuclear Power - Deployment, Operation and Sustainability, Dr. Pavel Tsvetkov (Ed.), ISBN: 978-953-307-474-0, InTech, Available from: http://www.intechopen.com/books/nuclear-power-deployment-operation-and-sustainability/a-novel-approachto-spent-fuel-pool-decommissioning

\section{INTECH}

open science | open minds

\section{InTech Europe}

University Campus STeP Ri

Slavka Krautzeka 83/A

51000 Rijeka, Croatia

Phone: +385 (51) 770447

Fax: +385 (51) 686166

www.intechopen.com

\section{InTech China}

Unit 405, Office Block, Hotel Equatorial Shanghai

No.65, Yan An Road (West), Shanghai, 200040, China

中国上海市延安西路 65 号上海国际贵都大饭店办公楼 405 单元

Phone: +86-21-62489820

Fax: $+86-21-62489821$ 
(C) 2011 The Author(s). Licensee IntechOpen. This chapter is distributed under the terms of the Creative Commons Attribution-NonCommercialShareAlike-3.0 License, which permits use, distribution and reproduction for non-commercial purposes, provided the original is properly cited and derivative works building on this content are distributed under the same license. 